J. Product. \& Dev., 14(2): $411-433(2009)$

\title{
IMPROVING WATER USE EFFICIENCY AND YIELD OF MAIZE (Zea mays, L.) BY FOLIAR APPLICATION OF GLYCINEBETAINE UNDER INDUCED WATER STRESS CONDITIONS
}

\author{
M. Abd Alla Kotb *, A. A. Mansour** and A. B. Gaballah** \\ * Department of Agronomy, Faculty of Agriculture, Suez Canal University, \\ Ismailia, Egypt. \\ ** Plant Production Department (Agronomy), Institute of Efficient \\ Productivity, Zagazig University, Egypt.
}

\section{ABSTRACT}

Two field experiments were conducted in a sandy soil in the extension field in El-Kassasein, Ismailia Governorate, Egypt during 2007 and 2008 summer seasons. The work aimed to study the effect of five levels of glycinbetaine $(0,5,10,15,20 \mathrm{mM} / \mathrm{fad})$ on the response of SC 10 maize hybrid to three rates of drip irrigation water (1.00. 0.80 and 0.60 of the estimated crop evapotranspiration, which represented 2625, 2100 and $1575 \mathrm{~m}^{3}$ water/fad, respectively). The most important findings could be summarized as follows:

Irrigation by $1575 \mathrm{~m}^{3} /$ fad instead of $2625 \mathrm{~m}^{3} / \mathrm{fad}$ reduced significantly ear leaf blade area, total chlorophyll, relative water content and leaf water potential, except the content of GB in leaves which was significantly increased in both seasons. Meanwhile, increasing the level of glycinebetaine $(G B)$ up to $15 \mathrm{mM} /$ fad increased these traits and the content of $G B$ in leaves compared with their untreated analogues.

Decreasing the amount of irrigation water from 2625 to 1575 $\mathrm{m}^{3} /$ fad reduced significantly the grain yield, protein yield and water use efficiency (IWUE). While, the relative increase percentages due to application of $15 \mathrm{mM} \mathrm{GB/fad} \mathrm{compared} \mathrm{with} \mathrm{zero} \mathrm{GB} \mathrm{were} 28.47$ and $25.30 \%, 54.53$ and $47.25 \%$, and 27.61 and $25.10 \%$ for these traits in both seasons, respectively.

The interaction between both studied factors showed that under moderate water stress condition $\left(2100 \mathrm{~m}^{3} / \mathrm{fad}\right)$ without $\mathrm{GB}$ addition the responses of these traits were only 11.59 and 10.77 ardab/fad, 135.29 
and $119.69 \mathrm{~kg} / \mathrm{fad}$ and 0.773 and $0.718 \mathrm{~kg} \mathrm{~m}^{-3}$ compared with 14.31 and $13.49 \mathrm{ardab} / \mathrm{fad}, 195.07$ and $176.25 \mathrm{~kg} / \mathrm{fad}$ and 0.954 and $0.899 \mathrm{~kg}$ $\mathrm{m}^{-3}$ when the concentration of $\mathrm{GB}$ was increased to $15 \mathrm{mM} \mathrm{GB/fad}$ in both seasons, respectively.

Key words: Maize, glycinebetaine, IWUE, drought, evapotranspiration.

\section{INTRODUCTION}

Maize is one of the most important cereal crops, which plays a critical role in animals and human feeding not only in Egypt but also in, almost, all countries. The total maize consumption has been increased drastically due to the over-growing population. Improving maize productivity can be achieved by breeding high yielding varieties and by application of improved agro-techniques. Water stress-associated with high temperature is often considered to be a limiting factor in maize (Zea mays L.) grown under arid and semiarid regions. Drought has different effects on grain yield depending on the developmental stage at which it occurs. It has been reported that maize is relatively tolerant to water stress in the vegetative stage, very sensitive during the period of tasseling, silking, and pollination, and moderately sensitive during the grain-filling stage (Shanahan and Nielsen, 1987 and Abo-El-Kheir and Mekki, 2007). Increasing water stress significantly decreased relative water content, chlorophyll content, leaf water potential (Shlemmer et al., 2005 and Premachandra et al., 2008), number of grains/ear, 1000-grain weight and grain yield (Muhammad et al., 2001). Thus water stress is the most important limitation on corn productivity in arid and semiarid regions.

Accumulation of solutes, either actively or passively, is an important adaptation mechanism for plants in response to osmotic stress. The accumulation of stress metabolites like proline, sugars, amino acids and betaines to maintain structural and metabolic integrity, occurs in response to drought and other stresses. Glycinebetaine (N, N, and N- trimethylglycine) is accumulated by many species of Gramineae, Amaranthaceae, Malvaceae and Poaceae families. Glycinebetaine (thereafter referred to as betaine) is a common compatible solute in many different organisms, including higher plants (Grote et al., 1994 and Rhodes and Hanson, 1993).

Using foliar application of glycinebetaine (GB) protects the plant by acting as an osmolytic and hence maintaining the water balance between the 
plant cell and the environment and by stabilizing macromolecules during cellular dehydration and at high salt concentration is a major goal for improving drought tolerance of plants in arid zones as in Egypt. Moreover, exogenous application of betaine to leaves or roots has been shown to increase the tolerance to various stresses of several species of plants, including both natural accumulators and non-accumulators (Mäkelä et al., 1996 and Allard et al., 1998). It has been shown that GB, when applied to foliage, is translocated from leaves to other plant parts within several hours (Mäkelä et al., 1996), where it acts as a non-toxic cytoplamic osmolyte and plays a central role in the protection of macrocomponents of plant cells, such as protein complexes and membranes, under stress conditions (Martin et al, 1997 and Jagendrof and Takab, 2001). It has also been reported that exogenous glycinebetaine led to increase photosynthetic activity, leaf area, leaf water potential, water use efficiency, total chlorophyll, relative water content and grain yield when it was applied to maize, sorghum, wheat and barley (Agboma et al., 1997, Naryyar and Walia, 2004, Abd Alla Kotb 2005, Abd Alla Kotb and Gaballah 2007 \& Nawaz and Ashraf 2007). When $12 \mathrm{mMGB} /$ fad was applied to barley plant under water stress, the flag leaf blade area, total chlorophyll, relative water content and grain yield were increased by 23\%, 35\%, 30\% and 24\%, respectively (Abd Alla Kotb and Gaballah 2007)

The present investigation aimed to investigate the effect of foliar application of glycinebetaine to improve drought tolerance of maize grown under induced water limited conditions.

\section{MATERIALS AND METHODS}

Two field experiments were conducted in a sandy soil in the extension field in El-Kassasein, Ismailia Governorate, Egypt $\left(30^{\circ} 58^{\prime} \mathrm{N}, 32^{\circ} 23^{\prime} \mathrm{E}\right.$, and $10 \mathrm{~m}$ above mean sea level) during 2007 and 2008 summer seasons. The study aimed to find out the effect of five levels of glycinbetaine $(0,5,10,15$, $20 \mathrm{mM} / \mathrm{fad}$ ) on SC 10 maize hybrid under three amounts of irrigation water (1.00. 0.80 and 0.60 of the estimated crop evapotranspiration) using drip irrigation system. A split plot design with three replicates was used in each season. The irrigation treatments and the levels of GB were randomly allocated in the main and sub-plots, respectively.

Three amounts of irrigation water were calculated as 0.6 (IR1), 0.8 (IR2) and 1.0 (IR3) of the estimated crop evapotranspiration (Etc). Maize 
plants were given 22 irrigations at 4 days intervals starting after 24 days from sowing. In the two growing seasons, the amount of water needed for each irrigation was calculated according to the crop coefficient $(\mathrm{Kc})$ and the daily reference potential evapotranspiration (ETo). The latter was determined according to the Penman-Monteith equation (Allen et al., 1998) depending on the predicted climatic factors at each irrigation time and the growth stage of maize plant. As recommended by Allen et al. (1996) and Neale et al. (1996), the FAO Kc of maize plant were 0.40 for initial stage, 0.80 for crop development stage, 1.15 for mid-season stage and 0.70 for last-season stage. At the end of the last irrigation, the quantity of water applied for each of the three irrigation treatments was calculated according to the total amount of water added in the 22 irrigations for the two seasons. The average amounts of water during the two growing seasons were 1575,2100 and $2625 \mathrm{~m}^{3} /$ fad for the irrigation treatments, respectively.

Glycinebetaine (GB) levels (0 GB: spray with tap water, $5 \mathrm{mM}$ equal to $0.525 \mathrm{~kg} / \mathrm{fad}, 10 \mathrm{mM}$ equal to $1.050 \mathrm{~kg} / \mathrm{fad}, 15 \mathrm{mM}$ equal to $1.575 \mathrm{~kg} / \mathrm{fad}$ and $20 \mathrm{mM}$ equal to $2.1 \mathrm{~kg} / \mathrm{fad}$ ) were foliar applied in 80 liter water/fad after 28 , 48 and 68 days from sowing.

Some physical and chemical properties of the upper of $60 \mathrm{~cm}$ layer of the experimental field soil as well as the predicted monthly climatic data at Ismailia region during the growing seasons of corn are presented in Tables 1 and 2, respectively. Soil analysis was done at Institute of Efficient Productivity laboratories. Soil bulk density was determined by a classical method, using cylinders $100 \mathrm{~mm}$ wide and $60 \mathrm{~mm}$ height according to Grossmann and Reinsch (2002), while both field capacity and wilting point were determined following the method of Cassel and Nielsen (1986).

Table 1: Soil physical and chemical properties of the experimental field soil over the two seasons

\begin{tabular}{ccccccc}
\hline $\begin{array}{c}\text { Soil depth } \\
(\mathbf{c m})\end{array}$ & $\begin{array}{c}\text { Coarse } \\
\text { sand }(\boldsymbol{\%})\end{array}$ & $\begin{array}{c}\text { Fine sand } \\
(\boldsymbol{\%})\end{array}$ & $\begin{array}{c}\text { Silt } \\
(\boldsymbol{\%})\end{array}$ & Clay $(\boldsymbol{\%})$ & Texture & $\begin{array}{c}\text { Soil bulk } \\
\text { density }(\mathbf{g} \\
\left.\mathbf{c m}^{-3}\right)\end{array}$ \\
\hline $0-60 \mathrm{~cm}$ & 65.20 & 26.92 & 4.58 & 3.30 & sandy & 1.71 \\
\hline $\begin{array}{c}\text { Soil depth } \\
(\mathrm{cm})\end{array}$ & $\begin{array}{c}\text { Field } \\
\text { capacity } \\
(\%)\end{array}$ & $\begin{array}{c}\text { Wilting } \\
\text { point } \\
(\%)\end{array}$ & $\mathrm{pH}$ & $\begin{array}{c}\text { Organic } \\
\text { matter }(\%)\end{array}$ & $\begin{array}{c}\mathrm{EC} \\
\left(\mathrm{dS} \mathrm{m} \mathrm{m}^{-1}\right)\end{array}$ \\
\hline $0-60 \mathrm{~cm}$ & 7.42 & 1.51 & 7.7 & 0.18 & 0.37 \\
\hline
\end{tabular}


Table 2: The predicted monthly climatic data at Ismailia Governorate during the growing periods of corn in 2007 and 2008 seasons.

\begin{tabular}{|c|c|c|c|c|c|c|c|c|c|c|}
\hline \multirow{4}{*}{ Months } & \multicolumn{6}{|c|}{ Average temperature ${ }^{0} \mathrm{C}$} & \multirow{2}{*}{\multicolumn{2}{|c|}{ Average RH (\%) }} & \multirow{3}{*}{\multicolumn{2}{|c|}{$\begin{array}{c}\text { Average } \\
\text { Wind speed } \\
(\mathbf{K m} / \mathbf{h})\end{array}$}} \\
\hline & \multicolumn{2}{|c|}{ Minimum } & \multicolumn{2}{|c|}{ Maximum } & \multicolumn{2}{|c|}{ Average } & & & & \\
\hline & 2007 & 2008 & 2007 & 2008 & 2007 & 2008 & 2007 & 2008 & & \\
\hline & 2001 & 2000 & 2001 & 2000 & 2001 & 2000 & & & 2007 & 2008 \\
\hline May & 15 & 15 & 30 & 27 & 22.5 & 21 & 45 & 50 & 15 & 14 \\
\hline June & 20 & 22 & 31 & 34 & 25.5 & 28 & 52 & 52 & 12 & 13 \\
\hline July & 24 & 24 & 33 & 35 & 28.5 & 29.5 & 55 & 64 & 13 & 13 \\
\hline August & 25 & 23 & 35 & 36 & 30 & 29.5 & 59 & 68 & 11 & 12 \\
\hline September & 24 & 23 & 36 & 32 & 30 & 27.5 & 64 & 61 & 11 & 11 \\
\hline
\end{tabular}

Data collected from Agriculture Research Center Meteorological Station in Ismailia

The sowing date was 25 May in both seasons in hills $20 \mathrm{~cm}$ apart. The sub-plot area was $16.8 \mathrm{~m}^{2}$ included 6 rows of $4 \mathrm{~m}$ long and $70 \mathrm{~cm}$ apart. The preceding crop was lupine in the two growing seasons. To ensure full germination, $27 \mathrm{~mm}$ of irrigation was applied to the all field area at planting. In addition, $37 \mathrm{~mm}$ was applied at 20days for complete establishment of seedlings. Irrigation was scheduled every 4 days throughout the growth period. Twenty days after sowing, maize plants were thinned to one plant/hill. Nitrogen fertilizer was applied at a level of $120 \mathrm{~kg} \mathrm{~N} / \mathrm{fad}$ as ammonium sulphate $(20.5 \% \mathrm{~N})$ in four equal doses, every 12 days from 20 days after sowing. Phosphorus fertilizer was applied at a level of $100 \mathrm{~kg}$ $\mathrm{P}_{2} \mathrm{O}_{5} / \mathrm{fad}$ as calcium superphosphate $\left(15.5 \% \mathrm{P}_{2} \mathrm{O}_{5}\right)$. Potassium fertilizer was applied at a level of $50 \mathrm{~kg} \mathrm{~K}_{2} \mathrm{O} / \mathrm{fad}$ as potassium sulphate $\left(48 \% \mathrm{~K}_{2} \mathrm{O}\right)$. Phosphorus and potassium fertilizers were applied before sowing in all treatments. The other agronomic practices were done as recommended.

At 85 days from sowing, five plants were randomly taken for estimating the vegetative growth characters as follows:

1- Ear leaf blade area $\left(\mathrm{cm}^{2}\right)$.

2- Total chlorophyll $\left(\mu \mathrm{Mm}^{-2}\right)$, it was determined using the Minolta SPAD502 chlorophyllmeter according to Markwell et al. (1995).

3- Leaf GB content ( $\mu \mathrm{g} / \mathrm{g}$ fresh weight), it was determined according to Gricve and Grattan (1983).

4- Relative water content (RWC):

The relative water content was determined according to Schonfeld et al., (1988), where the fresh weight of twenty discs, from the youngest fully expanded leaf, was determined within 2 hours after excision. Turgid weight 
was obtained after soaking the discs for 16 to 18 hours in distilled water. After soaking, discs were immediately and carefully blotted dried with tissue paper prior to the determination of turgid weight. Dry weight was obtained after drying the discs sample for 72 hours at $70 \mathrm{C}^{\circ}$. Relative water content was calculated using the following equation:

$$
\mathrm{RWC}=\frac{\text { Fresh weight }- \text { dry weight }}{\text { Turgid weight- dry weight }} \times 100
$$

5- Leaf water potential ( $-\psi)$, it was determined according to Edward (1967).

At harvest (120 days from sowing), the plants of the fourth and fifth rows $\left(5.6 \mathrm{~m}^{2}\right.$ areas) of each plot were used to determine:

1- Number of ears/plant.

2- Number of grains/ear.

3- 100-grain weight ( $\mathrm{g})$.

4- Grain yield ( $\mathrm{ardab} / \mathrm{fad}$ ), it was adjusted to $15.5 \%$ moisture content.

5- Grain $\mathrm{N}$ content (\%), it was measured using the modified microkijeldahl apparatus as described by A.O.A.C (1980).

6- Protein yield (kg/fad), It was calculated from multiplying grain yield in $\mathrm{kg} / \mathrm{fad}$ with grain nitrogen content and with 6.25 .

7- Irrigation water use efficiency (IWUE) in $\mathrm{kg} \mathrm{m}^{-3}$.

It was calculated as IWUE $=\mathrm{GY} / \mathrm{IR} \times 100$, where GY is grain yield $(\mathrm{kg} / \mathrm{fad})$ and IR is the amount of applied irrigation water $\left(\mathrm{m}^{3} / \mathrm{fad}\right)$ for each irrigation treatment.

The analysis of variance and least significant differences (LSD at 5\% levels) were used according to Steel et al. (1997).

\section{RESULTS AND DISCUSSION}

\section{1- Growth:}

The results in Table 3 indicate that each decrease in the amount of irrigation water from 2625 to $1575 \mathrm{~m}^{3} /$ fad decreased significantly and gradually the averages of ear leaf blade area, total chlorophyll, relative water content and leaf water potential but the content of GB in leaves was significantly and gradually increased in both seasons. The relative reduction percentages due to water stress were 40.41 and $43.93 \%, 39.90$ and $41.80 \%$, 46.54 and $46.63 \%$, and 17.78 and $20.70 \%$ for ear leaf blade area, total chlorophyll, relative water content and leaf water potential in both seasons, respectively. In the same trend, similar results 
were obtained by Shlemmer et al. (2005) and Premachandra et al. (2008) where they indicated that water stress reduced relative water content, chlorophyll content, and leaf water potential than their unstressed maize plants. It seems evident that subjecting maize plants to water stress, through reducing the amount of irrigation water reduced all growth attributes; probably due to impairing photosynthetic process which could have been decreased by the drastic decrease of leaf relative water content. These results are in agreement with those obtained by Talukder (1987), Abd Alla Kotb (2005) and Abd Alla Kotb and Gaballah (2007). Concerning to the increment of GB content in leaves due to water stress, it was reported that glycinebetaine is accumulated by many species of Gramineae in response to drought and other stresses (Rhodes and Hanson, 1993 and Grote et al., 1994). This increment in GB during water stress can not alleviate the negative effects of water lake on growth characters.

The effect of foliar application of GB on plant growth was significant in both seasons (Table 3). The highest values for growth attributes were obtained from application of $15 \mathrm{mM} \mathrm{GB} / \mathrm{fad}$ in both seasons except the leaf $\mathrm{GB}$ content which was increased by increasing the level of GB up to $20 \mathrm{mM} / \mathrm{fad}$ in the two seasons. Moreover, the results showed that the relative increase percentages due to application of $15 \mathrm{mM} \mathrm{GB} /$ fad were 24.51 and $27.66 \%$ for ear leaf blade area, 30.89 and $33.58 \%$ for total chlorophyll, 21.08 and $17.47 \%$ for leaf GB content, 19.88 and $24.99 \%$ for relative water content and 18.75 and $20.31 \%$ for leaf water potential in the first and second seasons, respectively compared with their untreated analogues. These results are in harmony with those obtained by Agboma et al. (1997), Abd Alla Kotb (2005) and Nawaz and Ashraf (2007). It is clear from the data recorded that increasing GB concentration to $20 \mathrm{mM}$ decreased ear leaf blade area, total chlorophyll, relative water content and leaf water potential in both seasons. This reduction of theses traits is seemed to be affected by the high concentration of exogenous glycinebetaine application. Results from other studies showed, also, that high concentration of GB could stimulate necrotic blotches on the leaves of wheat and could reduce above-ground biomass as reported by Agboma et al. (1997) and Abd Alla Kotb (2005)

Concerning the interaction between irrigation treatments and GB levels, results in Table 4 and Figures (1 to 5) showed that both of them interacted with each other significantly for all growth analysis. Ear leaf blade area, total chlorophyll, relative water content and leaf water potential were gradually and significantly increased by increasing both of irrigation water amount and GB 
ABD ALLA KOTB
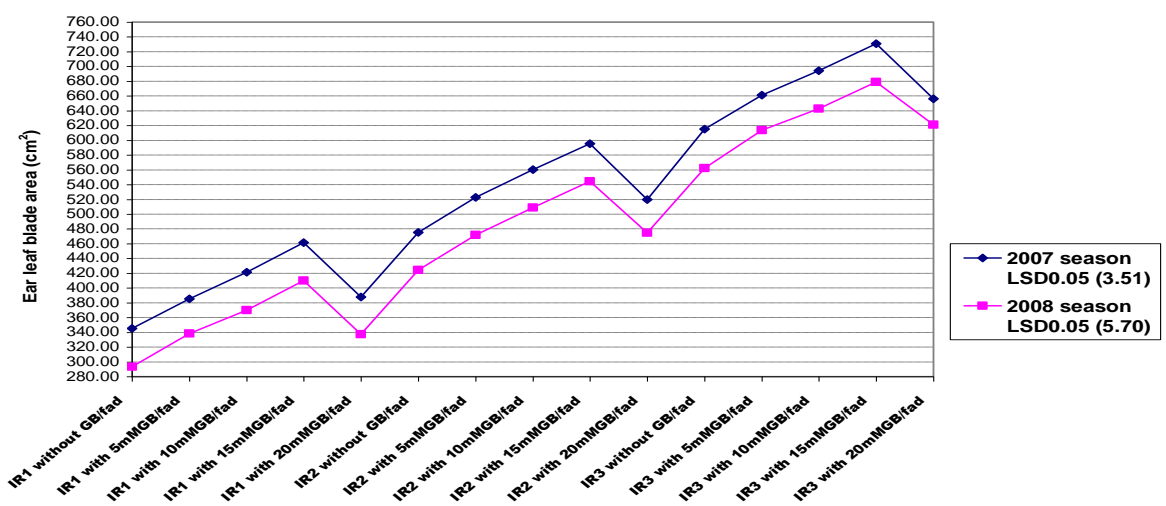

Figure 1: Interaction effect between water stress treatments and glycinebetaine levels (GB) on ear leaf blade area

(IR1, IR2 and IR3=1575, 2100 and $2625^{\mathrm{m}} 3 /$ fad, respectively)

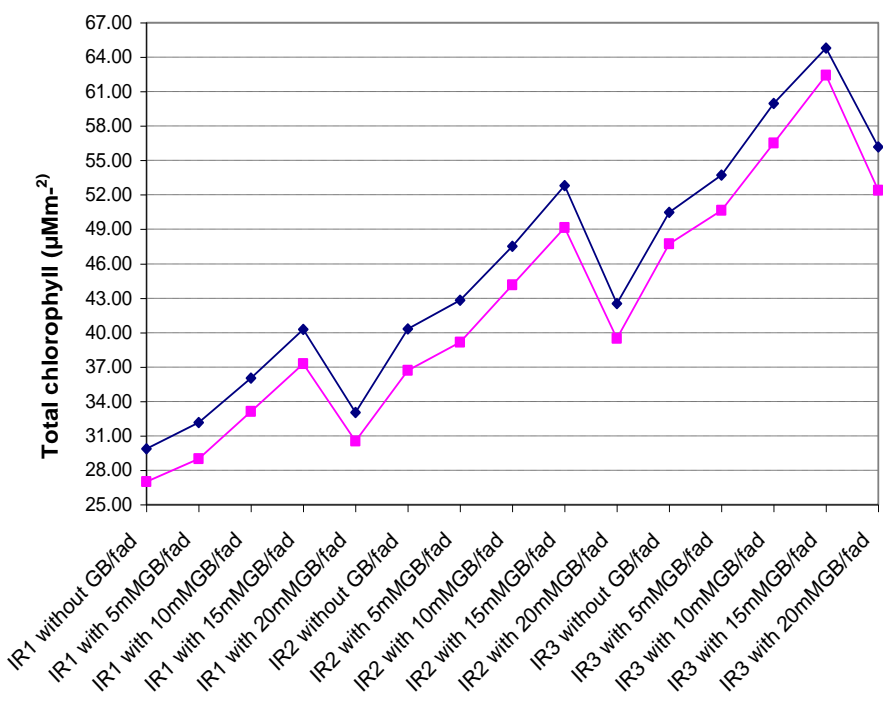

$\rightarrow-2007$ season

LSD0.05 (1.00)

-2008 season LSD0.05(0.98)

Figure 2: Interaction effect between water stress treatments and glycinebetaine levels (GB) on total chlorophyll $\left(\mu \mathrm{Mm}^{2}{ }^{2}\right)$

(R1, IR2 and IR3=1575, 2100 and $2625 \mathrm{~m}^{3} / \mathrm{fad}$, respectively) 


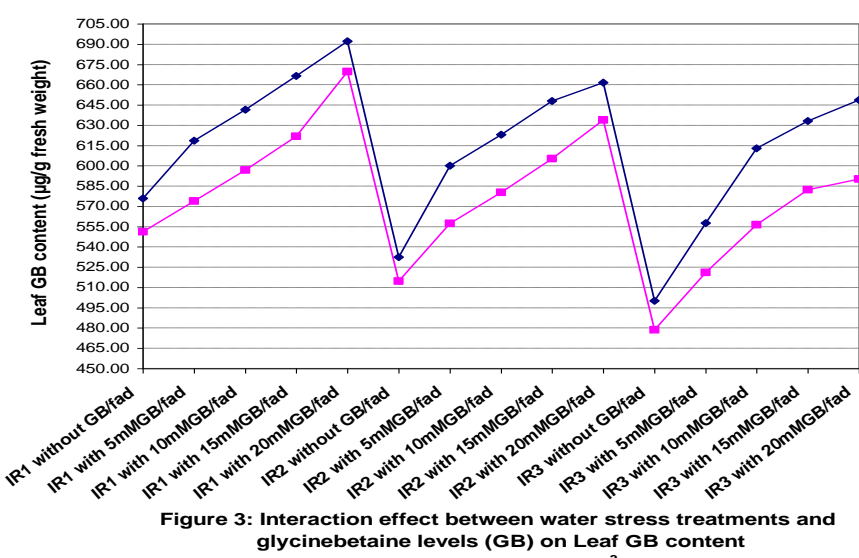

\begin{tabular}{|c|}
$\rightarrow-2007$ season \\
LSD0.05 $(12.97)$ \\
--2008 season \\
LSD0.05 $(15.94)$ \\
\hline
\end{tabular}

(R1, IR2 and IR3=1575, 2100 and $2625 \mathrm{~m}^{3} /$ fad, respectively)

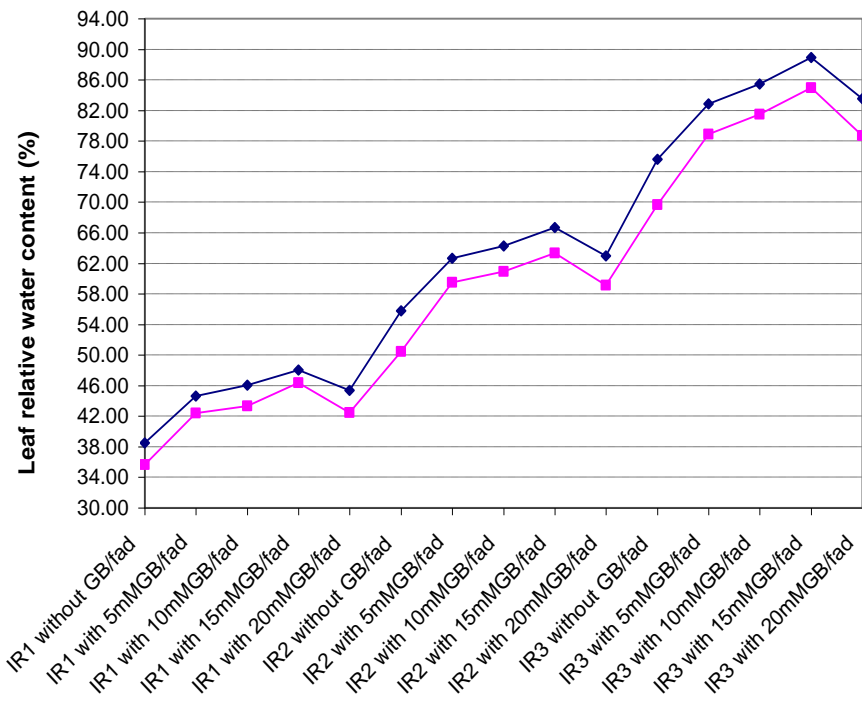

$\rightarrow-2007$ season

-2008 season

LSD 0.05 (1.45)

Figure 4: Interaction effect between water stress treatments and glycinebetaine (GB) on leaf relative water content

(R1, IR2 and IR3=1575, 2100 and 2625m3/fad, respectively) 


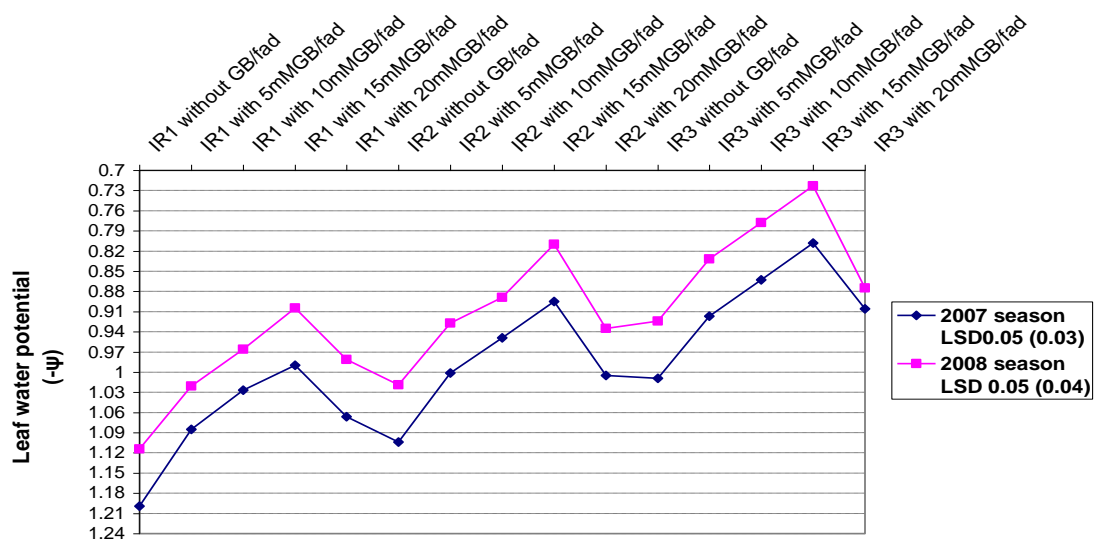

Figure 5: Interaction effect between water stress treatments and glycinebetaine levels (GB) on Leaf water potential $(-\Psi)$

(R1, IR2 and IR3=1575, 2100 and $2625 \mathrm{~m} 3 /$ fad, respectively)

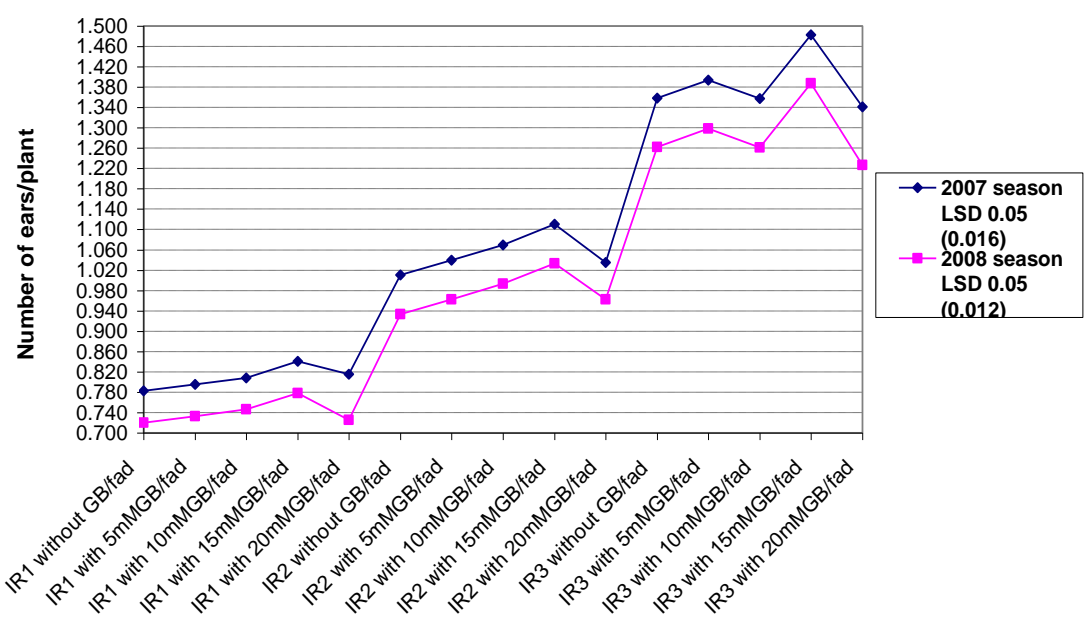

Figure 6 : Interaction effect between water stress treatments and glycinebetaine levels (GB) on number of ears/plant

(R1, IR2 and IR3=1575, 2100 and $2625 \mathrm{~m}^{3} / \mathrm{fad}$, respectively) 
levels up to $15 \mathrm{mM} / \mathrm{fad}$, except the content of $\mathrm{GB}$ in leaves which was significantly and gradually increased by decreasing the amount of water and increasing the exogenous application of GB up to $20 \mathrm{mM} / \mathrm{fad}$ in both seasons. In the same direction, Rhodes and Hanson, (1993) and Grote et al. (1994) reported that glycinebetaine is accumulated by many species of Gramineae in response to water stress.

Under the sever water stress treatment (0.6 of the estimated crop evapotranspiration) and spray with $15 \mathrm{mM} \mathrm{GB} / \mathrm{fad}$, the responses of ear leaf blade area, total chlorophyll, GB content, relative water content and leaf water potential were 461.30 and $410.10 \mathrm{~cm}^{2}, 40.29$ and $37.27 \mu \mathrm{Mm}^{-2}, 666.47$ and $621.80 \mu \mathrm{g} / \mathrm{g}$ fresh weight, 48.04 and $46.34 \%$, and 0.990 and $0.905(-\psi)$ compared with 345.30 and $293.30 \mathrm{~cm}^{2}, 29.88$ and 27.01_ $\mu \mathrm{Mm}^{2}, 575.97$ and $551.31 \mu \mathrm{g} / \mathrm{g}$ fresh weight, 38.47 and $35.63 \%$ and, 1.199 and $1.114(-\psi)$ when the concentration of GB was decreased to zero in both seasons, respectively. The highest values of ear leaf blade area, total chlorophyll, relative water content and leaf water potential were obtained from $15 \mathrm{mM} \mathrm{GB} /$ fad under un-stress irrigation treatment (normal irrigation) in both seasons. These results indicate, also, that maize plants responded to GB addition in both seasons under normal irrigation as well as water stress conditions.

From these results, it could be concluded that exogenous GB application with a proper dose helped stressed maize plants to accumulate more chlorophyll and GB contents, and hence had higher leaf area, relative water content and leaf water potential than their untreated analogues. This could be due to a possible increase in the stability of chloroplast membranes (Mamedove et al., 1991), protection of photosystem II by GB (Papageorgiou et al., 1991), improved water status and reduced transpiration via effects on stomatal regulation. These beneficial effects of GB might have had improved the growth of maize plants under water-stress conditions. These results are in harmony with those obtained by Abd Alla Kotb (2005), Abd Alla Kotb and Gaballah (2007) and Quanqi et al. (2008).

\section{2- Yield and water use efficiency:}

Decreasing the amount of irrigation water from 2625 to $1575 \mathrm{~m}^{3} / \mathrm{fad}$ reduced significantly the yield and its attributes in both seasons (Tables 5 and 6). The relative decrease percentages were 44.98 and $47.30 \%, 44.87$ and $44.67 \%$, 69.96 and $70.80 \%$, and 8.29 and $12.24 \%$ for grain yield, grain $N$ content, protein yield and water use efficiency in both seasons, respectively. In the same trend, the 
ABD ALLA KOTB 
Table 6. Effect of water stress treatments and glycinebetaine levels (GB) on protein yield and water use efficiency of maize in 2007 and 2008 seasons.

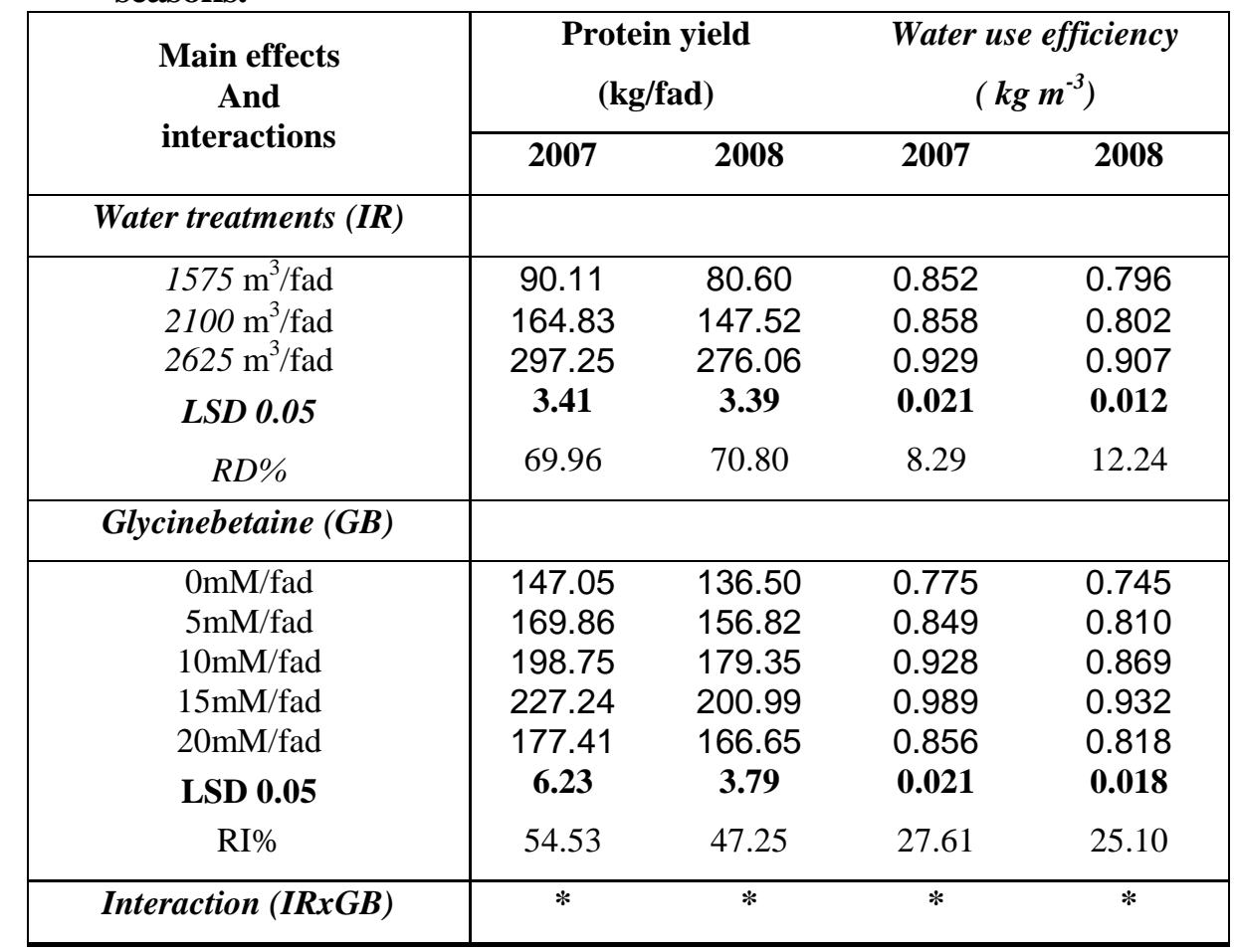

RD\%: Relative decrease percentage due to decreasing irrigation water amount from 2625 to $1575 \mathrm{~m}^{3} / \mathrm{fad}$

RI\%: Relative increase percentage due to increasing GB levels from zero to $15 \mathrm{M} / \mathrm{fad}$

results obtained by $\mathrm{Ni}$ (1992) referred that drought during the vegetative growth stage indirectly affected yield potential by adversely affected leaf area and photosynthetic capacity. These results are in agreement with those of Muhammad et al. (2001) and Abd Alla Kotb (2005).

In both seasons, the results showed that numbers of ears/plant, number of grains/ear, 100-grain weight, grain yield, grain $\mathrm{N}$ content, protein yield and irrigation water use efficiency were significantly affected by foliar application of GB. The results in Tables 5 and 6 revealed that $15 \mathrm{mM}$ GB produced the highest values for yield and yield attributes compared with the other treatments in both seasons. Foliar application of $15 \mathrm{mM}$ increased grain yield, grain $\mathrm{N}$ content, protein yield and 
irrigation water use efficiency by 28.47 and $25.30 \%, 19.38$ and $17.96 \%, 54.53$ and $47.25 \%$ and 27.61 and $25.10 \%$ compared with untreated plants in the first and second seasons, respectively. Augmentation GB concentration up to $20 \mathrm{mM} / \mathrm{fad}$ resulted in a significant decrease in values of yield and yield attributes. The increments in yield and yield attributes could be attributed to the increments in leaf blade area, total chlorophyll, relative water content and leaf water potential, which in turn resulted in higher values of dry matter accumulation per unit area and consequently higher yield and its attributes.

It is clear that exogenous glycinebetaine might have had increased photosynthetic activity, leaf area, leaf water potential, water use efficiency, total chlorophyll, relative water content and grain yield as reported in maize, sorghum, wheat and barley by Agboma et al., (1997), Naryyar and Walia (2004), Abd Alla Kotb (2005), Abd Alla Kotb and Gaballah (2007) and Nawaz and Ashraf (2007), in respective order.

In contrast, increasing application of GB to $20 \mathrm{mM} /$ fad decreased growth, yield and its components. This may be due to toxicity of GB when accumulated in higher concentration within cells and inhibition of metabolic process (Agboma et al., 1997 and Abd Alla Kotb, 2005). The obvious results indicate, also, that the content of GB in leaves was significantly and gradually increased by increasing the exogenous application of GB up to $20 \mathrm{mM} / \mathrm{fad}$.

Concerning the interaction between both studied factors in the two seasons, the results showed that both of them interacted with each other significantly for number of ears/plant, 100-grain weight, grain yield, protein yield and water use efficiency, but number of grains/ear and $\mathrm{N}$ content of leaves were not significantly affected.

The highest values of yield and yield attributes were obtained from applying $2625 \mathrm{~m}^{3} / \mathrm{fad}$ and spraying with $15 \mathrm{mM} \mathrm{GB} /$ fad compared with the same amount of irrigation water and without GB addition in both seasons (Table 7 and Figures 6 to 10). These results show, also, that with increasing level of GB in both seasons, yield and yield attributes did not respond to more than $15 \mathrm{mM}$ under normal irrigation or water stress and followed by a significant decrease in these traits.

The obtained results in Figures (6 to 10) indicate that grain yield, protein yield and water use efficiency ( $\mathrm{kg}$ grain $/ \mathrm{m}^{3}$ water) were increased up to 20.18 and $19.14 \mathrm{ardab} / \mathrm{fad}, 377.89$ and $329.39 \mathrm{~kg} / \mathrm{fad}$ and 1.076 and $1.021 \mathrm{~kg} \mathrm{~m}^{-3}$ with interaction $2625 \mathrm{~m}^{3}$ water/fad and $15 \mathrm{mM} \mathrm{GB} / \mathrm{fad}$ in comparison with 14.96 and 


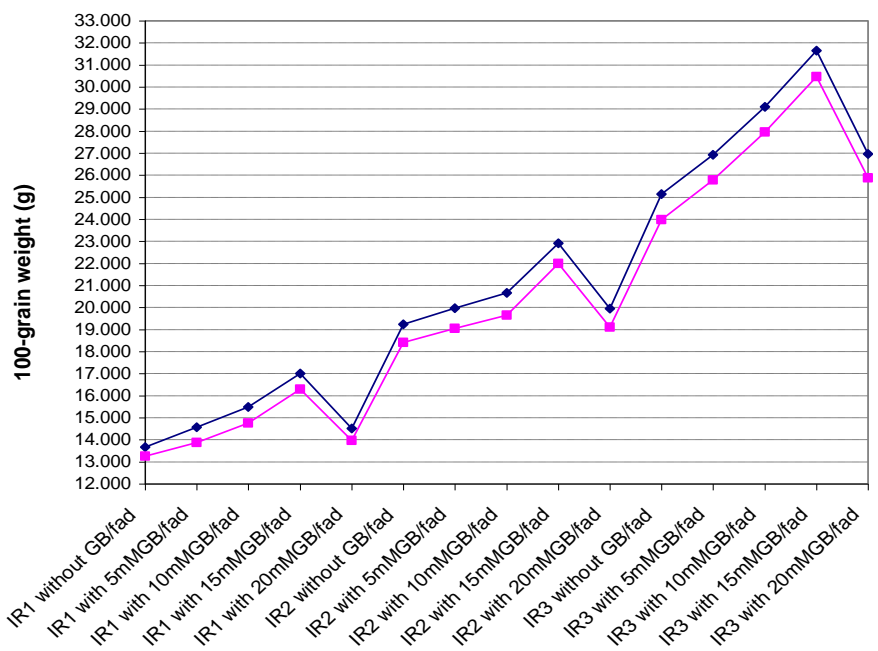

-2007 season LSD $0.05(0.20)$

-2008 season LSD $0.05(0.19)$

Figure 7: Interaction effect between water stress treatments and glycinebetaine levels (GB) on 100-grain weight

(R1, IR2 and IR3=1575, 2100 and $2625 \mathrm{~m}^{3} /$ fad, respectively)

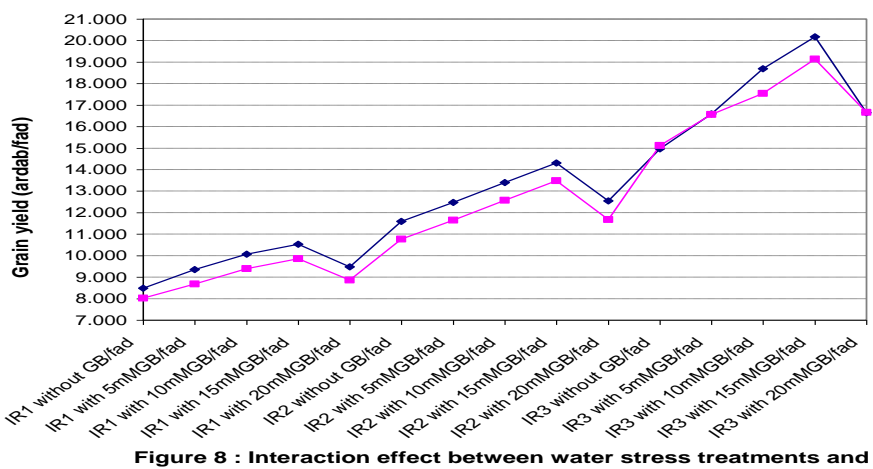
glycinebetaine levels (GB) on grain yield

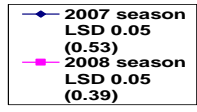
(R1, IR2 and IR3 $=1575,2100$ and $2625 \mathrm{~m}^{3} / \mathrm{fad}$, respectively) 

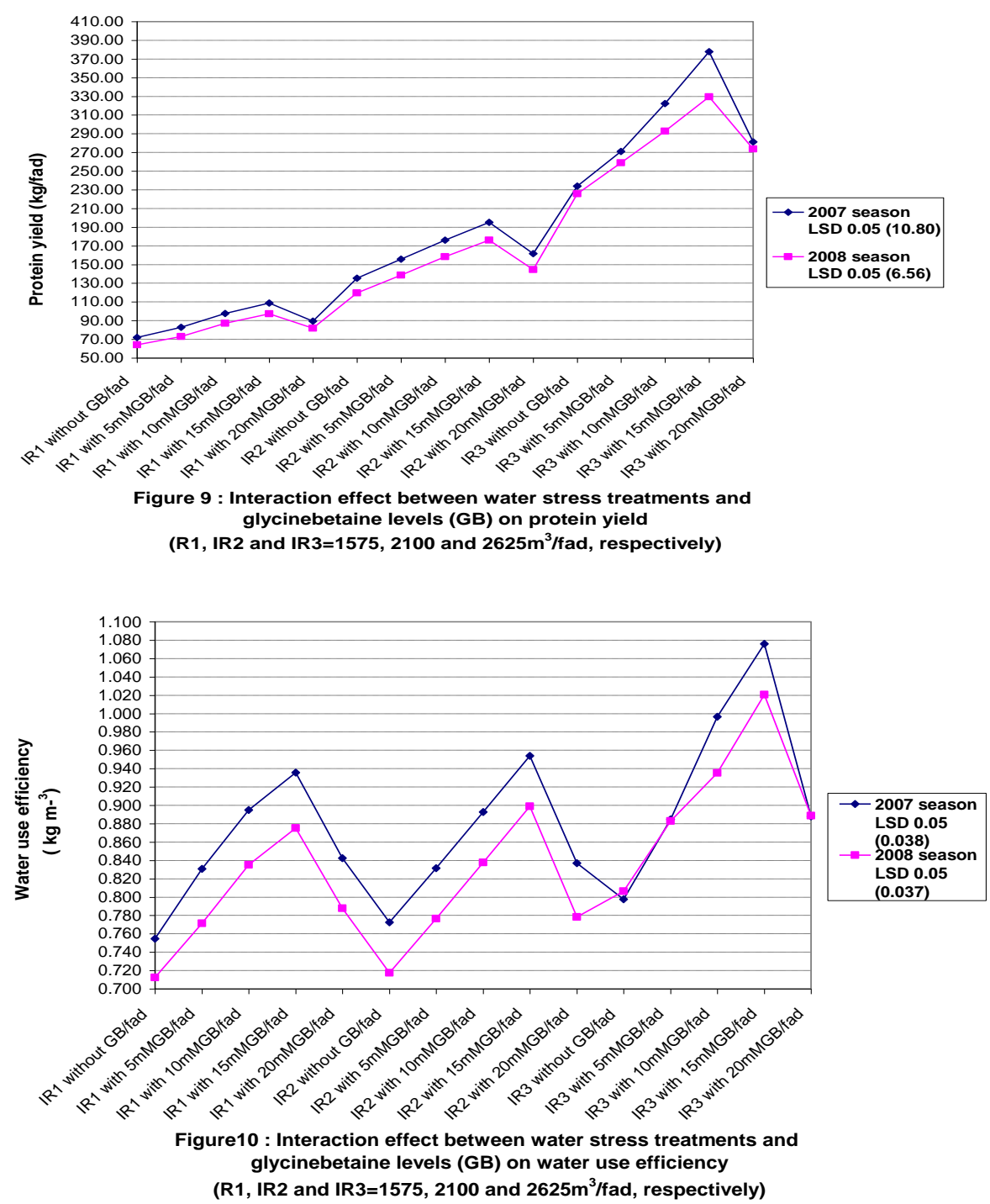

$15.11 \mathrm{ardab} / \mathrm{fad}, 233.95$ and $225.76 \mathrm{~kg} / \mathrm{fad}$ and 0.798 and $0.806 \mathrm{~kg} \mathrm{~m}^{-3}$ by using full irrigation and without GB in both seasons, respectively.

Under moderate and severe water stress conditions (2100 and $\left.1575 \mathrm{~m}^{3} / \mathrm{fad}\right)$, yield and yield attributes responded significantly up to $15 \mathrm{mMGB} / \mathrm{fad}$ compared with the interaction between water stress and without application GB in both 
seasons. Under moderate water stress condition $\left(2100 \mathrm{~m}^{3}\right)$ without $\mathrm{GB}$ addition the responses of grain yield, protein yield and irrigation water use efficiency were only 11.59 and $10.77 \mathrm{ardab} / \mathrm{fad}, 135.29$ and $119.69 \mathrm{~kg} / \mathrm{fad}$ and 0.773 and $0.718 \mathrm{~kg} \mathrm{~m}^{-3}$ compared with 14.31 and $13.49 \mathrm{ardab} / \mathrm{fad}, 195.07$ and $176.25 \mathrm{~kg} / \mathrm{fad}$ and 0.954 and $0.899 \mathrm{~kg} \mathrm{~m}^{-3}$ when the concentration of GB was increased to $15 \mathrm{mM} \mathrm{GB}$ in both seasons, respectively. In the same observation, exogenous application of GB to low-accumulating or non-accumulating plants may help to reduce the adverse effects of environmental stresses (Mäkela et al., 1996 \&Yang and Lu, 2005).

These results mean that maize plants responded to GB application in the both seasons under water stress conditions as well as under un-stressed conditions. It was clear that GB played a crucial role as osmoprotectants in improving the tolerance of plants to environmental stresses. The foliar application of glycinebetaine on maize plants increased nitrogen uptake, leaf area, leaf water potential, total chlorophyll, relative water content. The increase of these traits can improved water use efficiency and both of the maize grain and protein yields. These results may explain the reported response of maize plants to GB under water stress conditions (Agboma et al., 1997, Naryyar and Walia, 2004, Abd Alla Kotb (2005), Abd Alla Kotb and Gaballah 2007 \& Nawaz and Ashraf (2007).

Conclusively, from these results, it could be concluded that subjecting maize plants to water stress decreased significantly growth, yield and its attributes. Meanwhile, exogenous application of GB by a proper level $(15 \mathrm{~m} \mathrm{M} / \mathrm{fad})$ enhanced growth, yield and its attributes. Moreover, the interactions between water treatments and levels of GB were significant, indicating that GB played an important role for minimizing the adverse effect of water stress and hence improved water use efficiency, grain and protein yields. From these previous results it could be concluded that glycinebetaine (GB) acted as osmoregulating substance and enhanced the tolerance of maize plants to water stress when was applied at a level of $15 \mathrm{mM} / \mathrm{fad}$. But foliar application of GB by a higher level $(20 \mathrm{mM} / \mathrm{fad})$ decreased growth and yield, probably, due to a possible inhibition of photosynthesis.

\section{REFRENCES}

Abd Alla Kotb, M. (2005) Effect of foliar application of glycinebetaine on growth and yield of wheat (Triticum aestivum L.) under water stress. The 
$11^{\text {th }}$ Conference of Agronomy, Agronomy Department, Faculty Agriculture, Assiut Univ., Nov. 15-16., 65-79.

Abd Alla Kotb, M. and A. B. Gaballah (2007) Influence of glycinebetaine and nitrogen levels on growth and yield of barley (Hordeum vulgare L.) under drought conditions. Journal of Productivity and Dev. 12 (1): 45-60.

Abo -El-Kheir, M. S. A. and B. B. Mekki, (2007). Response of maize single cross-10 to water deficits during silking and grain filling stages. World Journal of Agriculture Science, 3(3): 269-272.

Agboma P. C.; Jones; M. G. K.; Peltonen-Sainio, P.; Rita, H. and E. Pehu, (1997). Exogenous glycinebetaine enhances grain yield of maize, sorghum and wheat grown under two supplementary watering regimes. Journal of Agronomy and Crop Science, 178: 29-37.

Allard, F.; M .Houde; M. Krol; A. Ivanovand and F. Sarhan (1998). Betaine improves freezing tolerance in wheat. Plant Cell Physiol, 39: 1194-2202.

Allen, R.G., Smith, M., Willian, O., Pruitt, W.O. and L.S. Pereira (1996) Modifications to the FAO crop coefficient approach. In:Proceedings of the International Conference on Evapotranspiration and Irrigation Scheduling, American Society of Agricultural Engineering, San Antonio, TX, USA, November 3-6, pp. 132-142.

Allen, R.G., Pereira, L.S., Raes, D. and M. Smith (1998). Crop Evapotranspiration Guidelines for Computing Crop Water Requirements (Irrigation and drainage paper 56). FAO of the United Nations, Rome, Italy. Andrade, F.H., Echorte, L., Rizzalli, A.D., Casanovas, M., 2002. Kernel number prediction in maize under nitrogen or water stress. Crop Science, 42: 1173-1179.

A.O.A.C. (1980) Association of Official Agricultural Chemists. Official Methods of Analysis. $10^{\text {th }}$ Edition, A.O.A.C., Washington D.C.

Cassel, D.K. and D.R. Nielsen (1986). Field capacity and available water capacity. Methods of Soil Analysis. Part I. Physical and Mineralogical Methods. Agronomy Monograph No. 9, In: Klute, A. (ed.) Soil Sci. Soc. Am., Madison, Wisconsin, pp. 901-926.

Edward, B. Kinpling (1967). Measurements of leaf water potential by the dye method. Ecology, 48 (6): 1038-1041.

Gricve, C. M. and S. R. Grattan (1983). Rapid assay for determination of water soluble quaternary ammonia compound. Plant Soil, 70: 303-307. 
Grossmann, R.B. and T.G. Reinsch (2002). Bulk density and linear extensibility, in: Methods of Soil Analysis. Part 4. Physical Methods. SSSA Book Series, No. 5, Soil Science Soc. Am., Madison, Wisconsin, pp. 201-228.

Grote, E. M., G. Ejeta and D. Rhodes (1994). Inheritance of glycinebetaine deficiency in sorghum. Crop Science, 34:1217-1220.

Jagendrof, A. T. and Takab, T. (2001) Inducers of GB synthesis in barley. Plant Physiology, 127: 1827-1835.

Mäkelä P.; Peltonen-Sainio P.; Jokinen K.; Pehu E.; Setala H.; Hinkkanen R. And S. Somersalo (1996). Uptake and translocation of foliar-applied glycinebetaine in crop plants. Plant Sci., 121: 221-230.

Mamedov, M.; Hayashi H.; Wada H.; Mohanty PS.; Papageoriou, GC. and N. Murata (1991) Glycinebetaine enhances and stabilizes the evolution of oxygen and the synthesis of ATP by cyanobacterial thylakoid membranes. FFBS Lett., 294: 271-274.

Markwell, J., J. C. Osterman and J. L. Mitchell (1995). Calibration of Minotta SPAD-502 leaf chlorophyllmeter. Photosynthetic Research, 46: 467-472.

Martin, M.; Morgan, J. A.; Zerbi, G. and D. R. Lecaain (1997). Water stress imposition rate affects osmotic adjustment and cell wall properties in winter wheat. Italian Journal of Agronomy, 1: 11-20.

Muhammad, B. K.; N. Hussain and M. Iqbal (2001). Effect of water stress on growth and yield components of maize variety YHS202. Journal of Research (Sci.), 12 (1): 15-18.

Neale, C.M.U., Ahmed, R.H., Moran, M.S., Pinter, J.P., QI, J. and T.R. Clarke (1996). Estimating cotton seasonal evapotranspiration using canopy reflectance. Proceedings of the International Conference on Evapotranspiration and Irrigation Scheduling, American Society of Agricultural Engineering, San Antonio, Texas, USA, November 3-6, 173-181.

Nayyar, H. and Walia, D. P. (2004). Genotypic variation in wheat in response to water stress and abscisic acid-induced accumulation of osmolytes in developing grains. Journal of Agronomy and Crop Science, 190: 39-45.

Nawaz, K. and M. Ashraf (2007) Improvement in salt tolerance of maize by exogenous application of glycinebetaine: growth and water relations. Pak. Journal of Bot., 39(5): 1647-1653. 
Ni, B. R. (1992). Stomatal and stomatal limitations to net photosynthesis in seeding of woody angiosperms. Plant Physiology, 99: 1502-1508.

Papageoriou, G. C., Fujimura, Y. and N. Murata (1991). Protection of the oxygen-evolving Photosystem 11 complex by glycinebetaine. Biochim. Biophys. Acta, 1057: 361-366.

Premachandra, G. S.; H. Saneoka; K. Fujita and S. Ogata (2008) Water Stress and Potassium Fertilization in Field Grown Maize (Zea mays L.): Effects on Leaf Water Relations and Leaf Rolling. Journal of Agronomy and Crop Science, 170(3): 195-201.

Quanqi1, C. ; L. Yuhai; L. Mengyu1; Z. Xunbo; D. Baodi and Y. Songlie (2008) Water potential characteristics and yield of summer maize in different planting patterns. Plant Soil Environ, 54 (1): 14-19

Rhodes, D. and A. D. Hanson (1993). Quaternary ammonium and tertiary sulfonium compounds in higher plants. Annual Review Plant Physiology, Plant Mol. Biology, 44: 357-384.

Schonfeld, M. A.; R. C. Johnson; B. F. Carver, and D. W. Mornhinweg (1988). Water relations in winter wheat as drought resistance indicators. Crop Science, 28: 536-541.

Shanahan J.F. and D. C. Nielsen (1987). Influence of growth retardants (AntiGibberellins) on corn vegetative growth, water use, and grain yield under different levels of water stress. Agronomy Journal ,79:103-109.

Shlemmer, M. R.: D. D. Francis: J. F. Shanahan and J. S. Schepers (2005). Remotely measuring chlorophyll content in corn leaves with differing nitrogen levels and relative water content. Agronomy Journal, 97: 106-112.

Steel, G. D.; J. H. Torrie and D. A. Diskey (1997). Principles and Procedures of Statistics: A Biometrical Approach. $3^{\text {rd }}$ ed. Mc Graw-Hill, New York.

Talukder, M. S. U. (1987). Growth and development of wheat as affected by soil moisture stress. Indian Journal of Agriculture Science, 57: 559-564.

Yang, X. and C. Lu. (2005). Photosynthesis is improved by exogenous glycinebetaine in salt stressed maize plants. Physiology Plant, 124: 343-352. 


\section{تحسين كفاءة استخدام الماء ومحصول الأرة بالرش بالجلايسين بيتايين تحت ظروف استحداث إجهاد مائي}

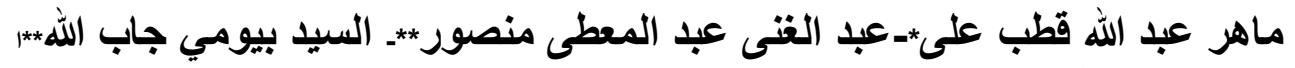

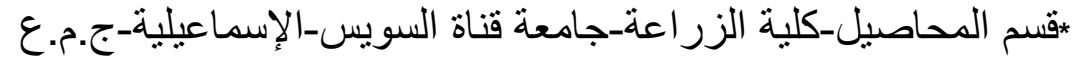

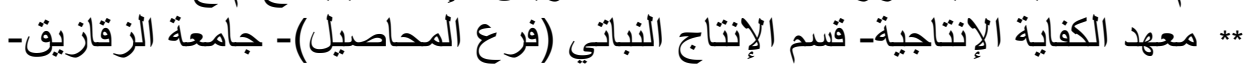

أجريت تجربتان حقليتان بارض رملية بمنطقة القصاصين بمحافظة

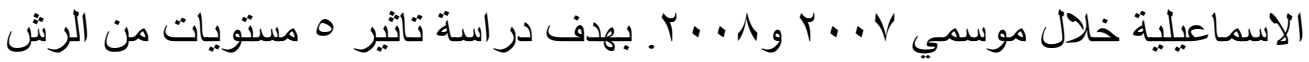

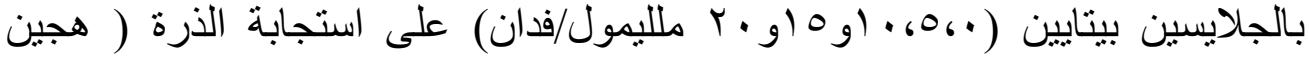

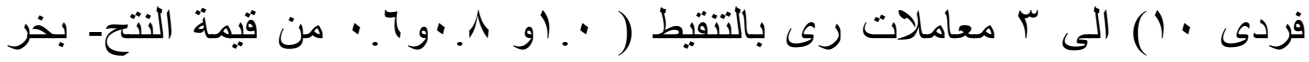

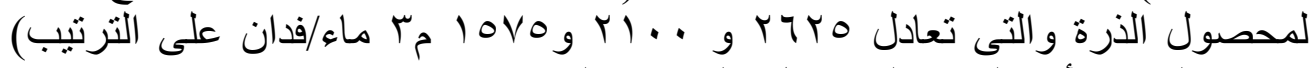

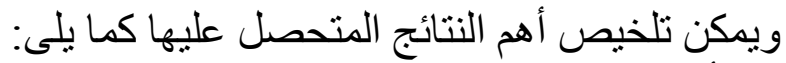

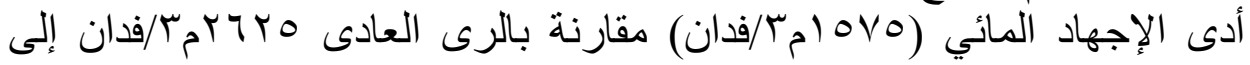

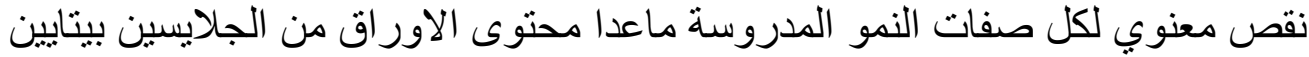

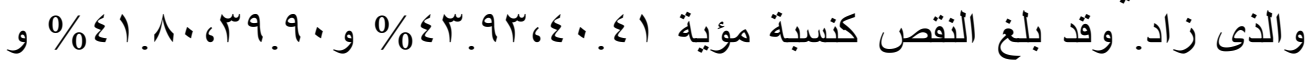
§

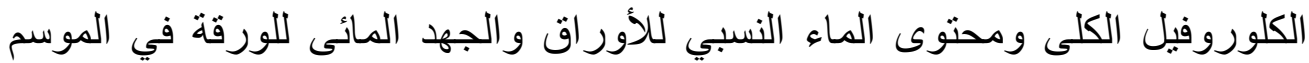

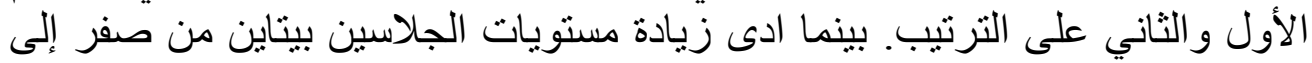

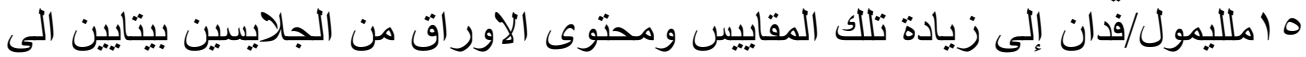

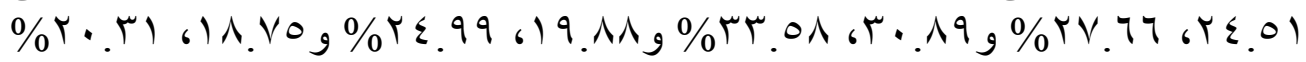

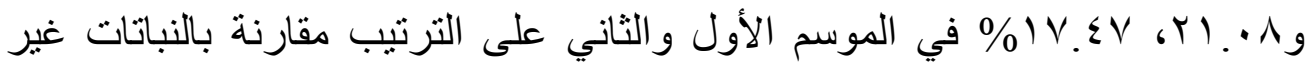

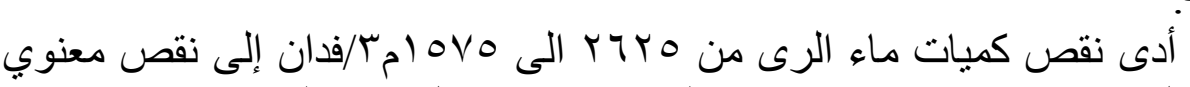

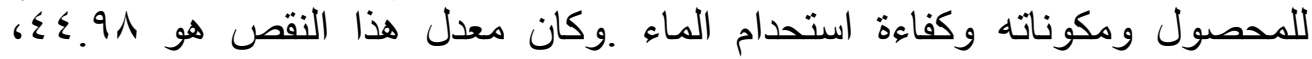
•

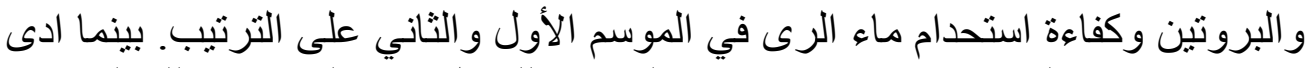

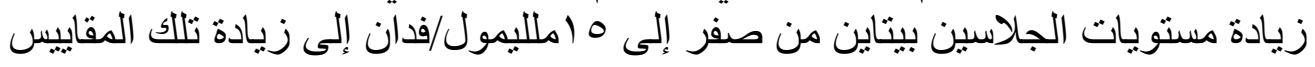




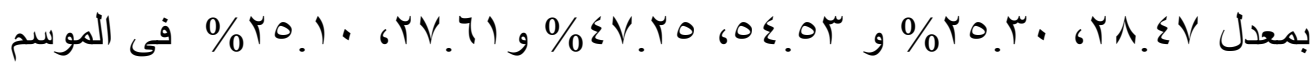
الاول و الثانى على الترنيب.

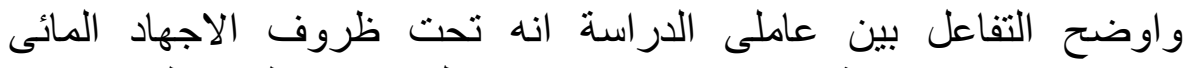

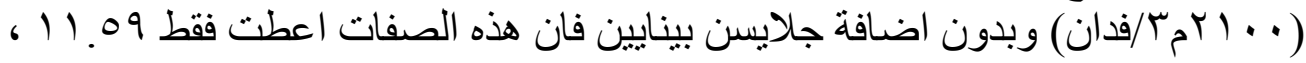

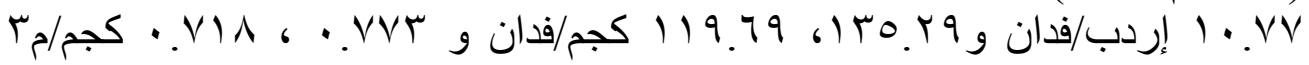

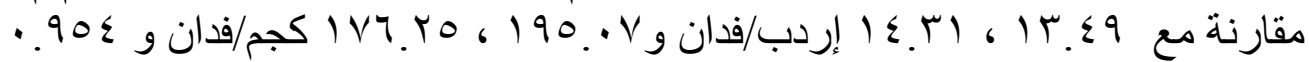

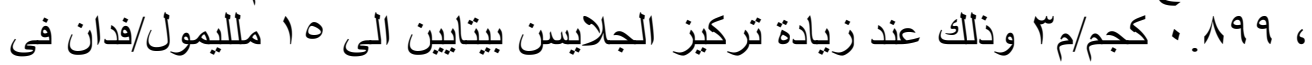
الموسم الاول و الثانى على الترثيب. 